\title{
PARTIAL CHARACTERIZATION OF ANTAGONISTIC SUBSTANCE PRODUCED BY A CLOSTRIDIUM BUTYRICUM STRAIN
}

\author{
Nely Cristina Medeiros Caires ${ }^{1}$; Aline Magalhães Matos²; Luiz de Macedo Farias²; Maria \\ Auxiliadora Roque de Carvalho²; Regina Maria Nardi Drummond²; Jacques Robert Nicoli²*; \\ Antônio Paulino Ribeiro Sobrinho ${ }^{1}$
}

${ }^{1}$ Departamento de Dentistica Restauradora, Escola de Odontologia, Universidade Federal de Minas Gerais, Belo Horizonte, MG, Brasil; ${ }^{2}$ Departamento de Microbiologia, Instituto de Ciências Biológicas, Universidade Federal de Minas Gerais, Belo Horizonte, MG, Brasil

Submitted: April 04, 2006; Returned to authors for corrections: August 24, 2006; Approved: January 21.

\begin{abstract}
The production of antagonistic substance by bacterium present in the infected root canal system (RCS) probably is an important ecological factor for its successful colonization of the local. The objective of this study was to partially characterize an antagonistic substance produced by a Clostridium butyricum isolated from infected RCS. Production of inhibitory compound was evaluated by the agar double layer diffusion technique using Fusobacterium nucleatum and Bifidobacterium adolescentis as indicator bacteria. The physicochemical and biochemical factors tested for the partial characterization were influence of $\mathrm{pH}$ and temperature and susceptibility to the action of some proteolytic enzymes. An inhibition zone was observed against the two indicator strains and acidity and bacteriophage were rejected as responsible for this phenomenon. The inhibitory activity showed to be decreasing in a $\mathrm{pH}$ range from 3.5 to 6.5 and being stable at temperatures of $60^{\circ}, 70^{\circ}$ and $100^{\circ} \mathrm{C}$, but completely inactivated when exposed at $121^{\circ} \mathrm{C}$. The antagonistic activity was resistant to the proteolytic action of trypsin, $\alpha$-chymotrypsin and papain. An antagonistic substance was produced by C. butyricum, which was thermo-resistant and probably of non-protein nature.
\end{abstract}

Key-words: Clostridium butyricum, Fusobacterium nucleatum, Bifidobacterium adolescentis, antagonism, root canal system.

\section{INTRODUCTION}

Bacterial interactions are one of the principal ecological determinants that regulate the establishment of an infecting microbiota in the root canal system (RCS) (21). Metabolic bacterial products may favor or inhibit the growth of other species (21). These products may be non-protein metabolites such as organic acids and hydrogen peroxide, or proteinaceous compound such as bacteriocins, which can be encoded genomically, but more often in plasmids $(2,24)$.

Bacteriocins constitute a heterogonous group of peptides and proteins highly variable in terms of activity spectrum, mode of action, molecular weight, genetic origin and biochemical properties (8). Depending on composition and structure, some bacteriocins can be resistant to temperature and proteolytic activities.

Non-protein metabolites are low molecular weight compounds (less than $1 \mathrm{KDa}$ ) that have a wider spectrum of action when compared to bacteriocins, being active against Gram-positive and Gram-negative bacteria as well as against fungi (12).

Antagonistic substances are probably important factors during infections involving RCS and there are few studies about the production of such substances by Clostridium spp. The objective of this study was to detect the production of this type of compound by a Clostridium butyricum strain and to partially characterize its chemical nature. This producer strain,

*Corresponding Author. Mailing address: Departamento de Microbiologia. Instituto de Ciências Biológicas. Universidade Federal de Minas Gerais. Caixa Postal 486, 30161-970, Belo Horizonte, MG, Brazil. Tel: (31) 3499-2757. E-mail: jnicoli@icb.ufmg.br 
as well as the sensitive ones (Bifidobacterium adolescentis and Fusobacterium nucleatum) were recovered in a previous work (11) from patient with pulpal necrosis.

\section{MATERIALS AND METHODS}

\section{Bacterial strains}

The three bacteria species used in this study were recovered from infected human root canals (11). Clostridium butyricum isolate was selected as the producer strain and B. adolescentis and $F$. nucleatum as indicator strains revealing the antagonism. The bacteria were stored at $-86^{\circ} \mathrm{C}$ in brain Heart Infusion broth (BHI, Difco Laboratories, Sparks, MD, USA) supplemented with glycerol 20\%. Recovery of strains was made in BHI broth supplemented with $0.5 \%$ yeast extract, $10 \mathrm{ig} / \mathrm{ml} \mathrm{hemin,} 1 \mathrm{ìg} / \mathrm{ml}$ menadione and $0.075 \%$ of L-cysteine (BHI-S, Difco).

\section{In vitro assay for production of antagonistic substances}

Agar double layer diffusion assay was used (8). The samples of C. butyricum and F. nucleatum were grown in BHI-S (Difco) and B. adolescentis in de Man, Rogosa and Sharp broth (MRS, Difco), and incubated at $37^{\circ} \mathrm{C}$, for 24 hours (B. adolescentis) and 48 hours (C. butyricum, F. nucleatum) in an anaerobic chamber (Forma Scientific Company, Marietta, OH, USA), containing an atmosphere of $\mathrm{N}_{2} 85 \%, \mathrm{H}_{2} 10 \%$ and $\mathrm{CO}_{2} 5 \%$ ). Then, spots of $5 \mu \mathrm{l}$ of the cultures were made onto BHI-S agar. The plates were incubated for periods of 24 hours and 48 hours, respectively, under the same anaerobic conditions. After incubation the plates were removed from the anaerobic chamber, exposed to chloroform vapor for 30 minutes and left semi-open for an equal period of time to allow evaporation of residual chloroform. Plates were covered with $3.5 \mathrm{ml}$ of soft agar $(0.75 \%$ BHI-S or $0.75 \%$ MRS according to indicator species), inoculated with approximately $10^{9}$ colony forming units (CFU) of the indicator bacteria (10) and incubated under the specific cultivation conditions for each one. The presence of an inhibition zone around the spot indicated the production of antagonist substances. Diameter of the inhibition halo was measured using a digital pachymeter (Mitutoyo Sul América Ltda, Suzano, SP, Brazil). Experiments were done in duplicate.

\section{Chemical characterization of antagonistic substances Preparation of crude extract}

Clostridium butyricum was grown initially in BHI-S broth and later in Clostridium broth (Difco) under anaerobiosis during 24 hours. After this period, the culture was centrifuged (RC5C centrifuge, Sorvall Instruments, Du Pont, Wilmington, DE, USA) at $4^{\circ} \mathrm{C}$ and $10,000 \times g$, for 10 minutes. The supernatant was filtered with a 0.22 ìm membrane (Millipore Corp., Bedford, MA, USA), divided into $15 \mathrm{ml}$ aliquots and stored at $-70^{\circ} \mathrm{C}$. After temperature equilibration, the supernatants were freeze dried (Free Zone 6 LITER, LABCONCO, Kansas City, MO, USA) and then suspended in ultra-pure sterile water to obtain a 10 fold concentration in relation to the initial aliquots.

\section{Testing bacteriophages as responsible of antagonism}

To evaluate phage as responsible for antagonistic activity, a $3 \mathrm{~mm}^{2}$ fragment of agar was aseptically removed from an inhibition zone (23). The fragment was placed onto BHI-S agar that was immediately recovered with BHI-S or MRS soft agar containing approximately $10^{7} \mathrm{CFU} / \mathrm{ml}$ of indicator strain. Presence of lytic zones was evaluated after 48 hours of anaerobic incubation at $37^{\circ} \mathrm{C}$. All experiments were done in duplicate.

\section{Testing acids as responsible for antagonistic activity}

Antagonistic assays were performed as described above and after development of antagonism. Medium $\mathrm{pH}$ was determined inside and outside the inhibition zone using a surface microelectrode (Microeletrodes Inc., Londonderry, NH, USA). Non-inoculated plates were used as control (4).

\section{Influence of temperature on antagonistic activity}

Crude extract aliquots of $50 \mu \mathrm{l}$ were submitted to thermal treatment at $60^{\circ} \mathrm{C}, 70^{\circ} \mathrm{C}$ and $100^{\circ} \mathrm{C}$ for 30 and 60 minutes, in a water bath, and at $121^{\circ} \mathrm{C}$ for 15 minutes, in an autoclave. These samples were then tested for remaining antagonistic activity using the well diffusion method carried out as follow. A punch was used to make $7 \mathrm{~mm}$ diameter wells in the BHI-S or MRS agar depth. To each well, an aliquot of $50 \mu \mathrm{l}$ was added and the plates immediately recovered with BHI-S or MRS soft agar containing approximately $10^{7} \mathrm{UFC} / \mathrm{ml}$ of the indicator strain, and incubated at $37^{\circ} \mathrm{C}$, for 24 and 48 hours to detect the inhibitory zone. Aliquots not exposed to temperature were used as control (7).

\section{Influence of $\mathrm{pH}$ on antagonist activity}

The $\mathrm{pH}$ of centrifuged and filtered crude extract aliquots was adjusted from 3 to 9 (with $5 \mathrm{~N} \mathrm{NaOH}$ or $5 \mathrm{~N} \mathrm{HCl}$ ). After freeze-drying and resuspension, the aliquots were re-filtered and tested for residual antimicrobial activity by the diffusion well method as described above. Crude extract with non-adjusted $\mathrm{pH}$ was used as control (7).

\section{Influence of proteolytic enzymes on antagonistic activity}

Crude extracts were concentrated by freeze-drying and resuspended to obtain a 10 fold concentration in relation to the initial volume. Then, $50 \mu \mathrm{l}$ of solutions containing each selected enzyme were added to achieve a final concentration of $1 \mathrm{mg} / \mathrm{ml}$. The following proteolytic enzymes were used: $\alpha$-chymotrypsin (E.C. 3.4.21.1, type II, Sigma-Aldrich, St. Louis, MO, USA), trypsin (E.C.3.4.21.4, type II, Sigma-Aldrich) and papain (E.C.3.4.23.1, Sigma-Aldrich), all dissolved in sodium phosphate buffer (50 mM, pH 7.0). The enzyme buffers and crude extracts were individually tested as control. After a one-hour period of incubation, at $37^{\circ} \mathrm{C}$, a $50-\mu \mathrm{l}$ aliquot was removed and tested by 
the diffusion well method. Disappearance of the inhibition zone indicated susceptibility to the specific enzyme $(3,4)$.

\section{RESULTS}

Clostridium butyricum showed antagonistic activity against both $F$. nucleatum and $B$. adolescentis. There was no evidence of cell lysis in the bacteriophage detection test, which discards this hypothesis as the cause of the antagonism. An accentuated reduction of $\mathrm{pH}$ was noted within the inhibition zone, when compared to the non-inoculated control plates, whose initial $\mathrm{pH}$ was of 6.47. However, using $F$. nucleatum as the indicator strain, a similar $\mathrm{pH}$ was obtained outside (4.42) and inside (4.44) the inhibition zone. Using $B$. adolescentis the values were of 4.14 and 4.16, respectively. These results demonstrate that acidity was not responsible for the inhibition of growth of the indicator bacteria.

The antagonistic activity remained stable at temperatures of $60^{\circ}, 70^{\circ}$ and $100^{\circ} \mathrm{C}$, independent of the time of exposure, being inactivated only when submitted to temperature of $121^{\circ} \mathrm{C}$ for 15 $\min$ (Table 1).

The antagonistic activity produced by $C$. butyricum decreased in a $\mathrm{pH}$ range from 3.5 to 6.5 for both indicator bacteria (Figure 1). Above these values ( $\mathrm{pH} 7.0$ to 9.0), inhibition halo was no more observed for both indicators strains. Inhibition was not observed for all the controls.

The antagonistic activity produced by $C$. butyricum was not inactivated by the proteolytic enzymes tested (Table 2).

Table 1. Influence of temperature exposure on antagonistic activity produced by Clostridium butyricum.

\begin{tabular}{lcc}
\hline \multirow{2}{*}{$\begin{array}{c}\text { Temperature } \\
\text { and exposure time }\end{array}$} & \multicolumn{2}{c}{ Indicator strains } \\
\cline { 2 - 3 } & F. nucleatum & B. adolescentis \\
\hline $60^{\circ} \mathrm{C}-30$ minutes & $13.77^{*} \pm 0.20$ & $12.14 \pm 0.55$ \\
$60^{\circ} \mathrm{C}-60$ minutes & $11.26 \pm 0.35$ & $9.74 \pm 0.15$ \\
$100^{\circ} \mathrm{C}-30$ minutes & $14.08 \pm 0.15$ & $17.37 \pm 0.95$ \\
$100^{\circ} \mathrm{C}-60$ minutes & $12.05 \pm 0.25$ & $13.47 \pm 0.51$ \\
$121^{\circ} \mathrm{C}-15$ minutes & 0 & 0 \\
Control & $12.78 \pm 0.25$ & $14.18 \pm 0.3$ \\
\hline
\end{tabular}

*Average size of inhibition halo $\pm \mathrm{SD}(\mathrm{mm})$.

\section{DISCUSSION}

Bacterial interaction has a determinant role in successful colonization by microorganisms of any particular niche. Through this mechanism, pioneer species may create conditions allowing others to be selected and thrive in succession as inhabitants of
Table 2. Influence of proteolytic enzymes on antagonistic activity produced by Clostridium butyricum.

\begin{tabular}{lcc}
\hline \multirow{2}{*}{ Experimental conditions } & \multicolumn{2}{c}{ Indicator strains } \\
\cline { 2 - 3 } & F. nucleatum & B. adolescentis \\
\hline Papain or chymotrypsin & 0 & 0 \\
or trypsin or buffer & $18.45^{*} \pm 0.55$ & $12.76 \pm 0.35$ \\
Papain + crude extract & & \\
$\alpha$-chymotrypsin + crude & $12.43 \pm 0.8$ & $15.93 \pm 0.47$ \\
extract & $13.00 \pm 0.65$ & $14.73 \pm 0.25$ \\
Trypsin + crude extract & $14.75 \pm 0.49$ & $14.47 \pm 0.60$ \\
Crude extract & & \\
\hline
\end{tabular}

*Average size of inhibition zone $\pm \mathrm{SD}(\mathrm{mm})$.

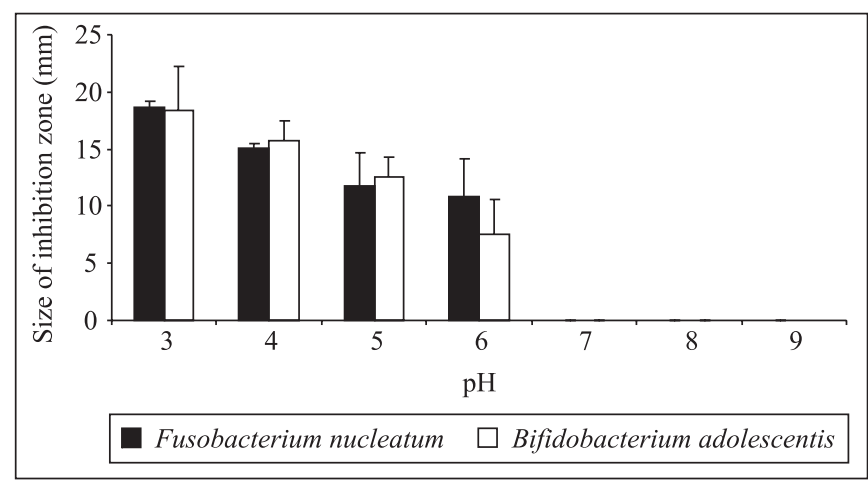

Figure 1. Influence of $\mathrm{pH}$ on antagonistic activity produced by Clostridium butyricum using Bifidobacterium adolescentis and Fusobacterium nucleatum as indicator strains. Results are the mean of two independent experiments. Vertical bars indicate standard error.

that ecosystem. On the other hand, the relationships may be antagonistic with competition of various bacteria for the same local. Numerous descriptions of such interactions can be found in the literature $(1,5,6,9,13,17,19,20)$, but many questions remain concerning the characterization of specific antagonistic compounds produced by bacteria involved in endodontic infection. Three recent reports demonstrated that a $C$. butyricum strain recovered from human root canal infection was able: i) to survive and translocate to local lymph nodes when inoculated into the root canal system of germ-free mice (14), ii) to modulate endodontic periapical response by an specific profile of cytokine produced in germ-free mice (15), and iii) to induce apoptosis of lymph node cells (16). The present study evaluated if this $C$. butyricum strain was also able to produce antagonistic substance in vitro. To demonstrate and characterize this possible antagonistic ability, two bacteria (B. adolescentis, $F$. 
nucleatum), also recovered from human root canal infection, were used as revelators (indicators).

Initially BHI-S medium was selected because clear and welldefined inhibitory zones were obtained in antagonism assays. However, an inhibitory activity was also observed when aliquots of the non-inoculated medium were concentrated to be used as control for the experiments of $\mathrm{pH}$ and temperature influence. Medium components, such as $\mathrm{NaCl}$, when concentrated during the procedures to obtain crude extract were probably responsible for these inhibition zones. There is a lack of information in the literature concerning culture media to be used for the characterization of antagonistic substances produced by bacteria of the genus Clostridium. The choice of Clostridium broth in our study is supported by Kemperman et al. (10), in its specific use for the production of bacteriocins by Clostridium. In the present study, antagonism assay using crude extracts from Clostridium broth produced smaller inhibitory zones when compared to those obtained with BHI-S medium, but antagonistic activity was not observed after concentration of control samples. Consequently, BHI-S medium was used only for detection of inhibitory phenomenon and bacteriophage and acidity assays while Clostridium broth was used for the partial characterization step.

In the antagonism test using the diffusion technique in agar, interference factors such as bacteriophages, hydrogen peroxide and organic acids must be discarded since their inhibition halos were very similar to those produced by bacteriocins (3). Activity of bacteriophage, as responsible for growth inhibition, was eliminated by a specific assay as well as hydrogen peroxide production because the strict anaerobic conditions used for the growth of both producer and indicator strains. Acetic and lactic acids exert an antagonistic effect not only by $\mathrm{pH}$ reduction of the culture medium, but also by anti-microbial action (3). Bacteria of the genus Clostridium have been reported to produce butyric, acetic, formic, lactic and succinic acids as well as butanol and ethanol (18). In this study acid production was not found to interfere in the inhibition of indicator strains (10) as demonstrated by similar $\mathrm{pH}$ values observed inside and outside the inhibition zones.

Clostridium shows optimum growth within a $\mathrm{pH}$ range from 4.5 to 5.0, and this fact influenced our choice to investigate $\mathrm{pH}$ values between 3 and 9 . It was shown that the antagonist effect against both target samples (B. adolescentis, and F. nucleatum) decreased from a maximum at $\mathrm{pH} 3.5$ to 6.5 and disappears near and above the neutrality.

With respect to the influence of temperature, antagonistic activity was maintained at temperatures of $60^{\circ}, 70^{\circ}$ and $100^{\circ} \mathrm{C}$, for time intervals of 30 and 60 minutes, but was inactivated when exposed at $121^{\circ} \mathrm{C}$, for 15 minutes. The stability of antagonistic compounds at high temperatures is a characteristic of non-protein substance, despite reports in the literature on some bacteriocins produced by Lactobacillus that showed to be thermotolerant (3). According to Tagg et al. (22), bacteriocins are inactivated by at least one proteolytic enzyme. In this study, the enzymes trypsin, $\alpha$-chymotrypsin and papain were not able to inactivate the antagonism produced by $C$. butyricum, another characteristic suggesting a non-protein compound.

In conclusion, a $C$. butyricum strain isolated from infected RCS produced an antagonistic activity against two bacteria also frequently recovered from the same site. The growth inhibition was not due to bacteriophage or acidity but to a substance that seems to be of non-protein nature. However, this substance must be better characterized and purified in future studies, since in vitro detection cannot be always extrapolated to in vivo conditions.

\section{ACKNOWLEDGMENTS}

This study was supported by grants from Coordenação de Aperfeiçoamento do Pessoal de Ensino Superior (CAPES) and Conselho Nacional de Pesquisa (CNPq). The authors acknowledge the graduation program of the Dental School/ UFMG and Maria Gorete Barbosa Ribas and Jamil Silvano Oliveira for technical help.

\section{RESUMO}

\section{Caracterização parcial de substância antagonista produzida por uma amostra de Clostridium butyricum}

A produção de substâncias antagonistas por espécies bacterianas presentes em sistema de canais radiculares (SCR) infectados, tem um papel importante na colonização deste sítio. O objetivo deste estudo foi caracterizar parcialmente a substância antagonista produzida por amostra de Clostridium butyricum isolado de SCR infectados. A produção de substância antagonista foi avaliada pela técnica de difusão em ágar utilizando como bactérias indicadoras Fusobacterium nucleatum e Bifidobacterium adolescentis. Os parâmetros físico-químicos utilizados durante a caracterização parcial foram: $\mathrm{pH}$, estabilidade térmica, susceptibilidade à ação das enzimas tripsina, $\alpha$-quimiotripsina e papaína. Foi observada zona de inibição contra as duas amostras indicadoras e ainda foi demonstrado que ácidos e bacteriófagos não eram responsáveis por este fenômeno. A atividade inibitória mostrou-se diminuída em uma faixa de $\mathrm{pH}$ de 3.5 a 6.5 e estável em temperaturas de $60^{\circ}$, $70^{\circ}$ e $100^{\circ} \mathrm{C}$, sendo completamente inativada quando exposta a $121^{\circ} \mathrm{C}$. A atividade antagonista foi resistente à ação das enzimas proteolíticas: tripsina, $\alpha$-quimiotripsina e papaína. A substância antagonista produzida por $C$. butyricum é termoresistente e provavelmente de natureza não protéica.

Palavras-chave: Clostridium butyricum, Fusobacterium nucleatum, Bifidobacterium adolescentis, antagonismo, sistema de canais radiculares. 


\section{REFERENCES}

1. Bolstad, A.L.; Jensen H.; Bakken V. (1996). Taxonomy, biology and periodontal aspects de Fusobacterium nucleatum. Clin. Microbiol. Rev., 9, 55-71.

2. Daeschel, A.M. (1989). Antimicrobial substances from lactic acid bacteria for use as food preservatives. Food Technol., 43, 91-94.

3. Drummond, R.M.N. (2001). Obtenção, caracterização e purificação parciais de substância antagonista produzida por Lactobacillus murinus. Rio de Janeiro, Brasil, 133p. (PhD thesis - Instituto de Microbiologia Professor Paulo de Góes - Universidade Federal do Rio de Janeiro)

4. Farias, L.M.; Carvalho, M.A.R.; Damasceno, C.A.V.; Cisalpino, E.O.; Vieira, E.C. (1992). Bacteriocin-like activity of Bacteroides fragilis group isolated from marmosets. Res. Microbiol., 143, 151159.

5. Gomes, B.P.F.A.; Drucker, D.B.; Lilley, J.D. (1994a). Association of specific bacteria with some endodontic signs and symptoms. Intern. Endodont. J., 27, 291-298.

6. Gomes, B.P.F.A.; Drucker, D.B.; Lilley, J.D. (1994b). Positive and negative associations between bacterial species in dental root canals. Microbios., 80, 231-243.

7. Gomez, S.; Cosson, C.; Deschamps, A.M. (1997). Evidence for a bacteriocin-like substance produced by a new strain of Streptococcus sp., inhibitory to Gram-positive food borne pathogens. Res. Microbiol., $148,757-766$

8. Jack, R.W.; Tagg, J.R.; Ray, B. (1995). Bacteriocins of Gram-positive bacteria. Microbiol. Rev., 59, 171-200.

9. Jung, L.L.; Choi, B.; Kum, K.; Roh, B.; Lee, S.; Lee, C.; Park, D (2000). Molecular epidemiology and association of putative pathogens in root canal infection. J. Endodont., 26, 599-604.

10. Kemperman, R.; Knipers, A.; Karsens, H.; Nauta, A.; Kuipers, O.; Kok, J. (2003). Identification and characterization of two novel clostridial bacteriocins, circularin A and clostricin 574. Appl. Environ. Microbiol., 69, 1589-1597.

11. Lana, M.A.; Ribeiro Sobrinho, A.P.; Stehling, R.; Garcia, G.D.; Silva, B.K.C.; Handam, J. S.; Nicoli, J. R.; Carvalho, M.A.R.; Farias, L.M. (2001). Microorganisms isolated from root canals presenting necrotic pulp and their drug susceptibility in vitro. Oral Microbiol. Immunol., 16, 100-105.
12. Niku-Paavola, M.L.; Laitila, A.; Mattila-Sandholm, T.; Haikara, A. (1999). New types of antimicrobial compounds produced by Lactobacillus plantarum. J. Appl. Microbiol., 86, 29-35.

13. Peters, L.B.; Wesselink, P.R.; Van Winkelhoff, A.J. (2002). Combinations of bacterial species in endodontic infections. Intern. Endodont. J., 35, 698-702.

14. Ribeiro Sobrinho, A.P.; Lanna, M.A.; Farias, L.M.; Carvalho, M.A.R.; Nicoli, J.R.; Uzeda, M.; Vieira, L.Q. (2001) Implantation of bacteria from human pulpal necrosis and translocation from root canals in gnotobiotic mice. J. Endodont., 27, 605-609.

15. Ribeiro Sobrinho, A.P.; Maltos, S.M.M.; Farias, L.M.; Carvalho, M.A.R.; Nicoli, J.R.; Uzeda, M.; Vieira, L.Q. (2002) Cytokine production in response to endodontic infection in germfree animals. Oral Microbiol. Immunol., 17, 344-353.

16. Ribeiro Sobrinho, A.P.; Rabelo, F.L.A.; Figueiredo, C.B.O.; Leite, J.I.A.; Nicoli, J.R.; Uzeda, M.; Vieira, L.Q. (2005) Bacteria recovered from dental pulp induce apoptosis of lymph node cells. J. Med. Microbiol., 54, 413-416.

17. Rôças, I.N.; Siqueira JR, J.F.; Santos, K.R.N.; Coelho, A.M.A. (2001) "Red complex" (Bacteroides forsythus, Porphyromonas gingivalis, and Treponema denticola) in endodontic infections: A molecular approach. Oral Surg. Oral Med. Oral Pathol., Oral Radiol. Endodont., 91, 468-71, 2001

18. Schink, B.; Ward, J.C.; Zeikus, J.G. (1981). Microbiology of wetwood: importance of pectin degradation and Clostridium species in living trees. Appl. Environ. Microbiol., 42, 526-532.

19. Siqueira, J.R., J.F.; Rôças, I.N. (2003a). Campylobacter gracilis and Campylobacter rectus in primary endodontic infections. Intern. Endodont. J., 36, 174-180.

20. Siqueira, J.R., J.F.; Rôças, I.N. (2003b). Pseudoramibacter alactolyticus in primary endodontic infections. J. Endodon., 29, 735-738.

21. Sundqvist, G. (1994). Taxonomy, ecology, and pathogenicity of the root canal flora. Oral Surg. Oral Med. Oral Pathol., 78, 522-530.

22. Tagg, J.R.; Dajani, A.S.; Wannamaker, L.M. (1976). Bacteriocins of Gram-positive bacteria. Bacteriol Rev., 40, 722-756.

23. Turner, J.W.; Jordan, H.V. (1981). Bacteriocin-like activity within the genus Actinomyces. J. Dental Res., 60, 1000-1007.

24. Zerr, M.A.; Cox, C.D.; Johnson, W.T.; Drake, D.R. (1998). Effect of red blood cells on the growth of Porphyromonas endodontalis and microbial community development. Oral Microbiol. Immunol., 13, 106-112. 